\title{
Supplementation levels for pre-weaning grazing beef heifers during the rainy-dry transition season
}

\section{Níveis de suplementação para bezerras de corte em pastejo na pré- desmama durante o período de transição águas-seca}

\author{
Victor Rezende Moreira Couto ${ }^{1 *}$; Mário Fonseca Paulino ${ }^{2}$; Sebastião de Campos \\ Valadares Filho²; Edenio Detmann²; Marlos Oliveira Porto ${ }^{3}$; Eriton Egídio Lisboa \\ Valente ${ }^{4}$; Cibelle Borges Figueiredo ${ }^{5}$
}

\begin{abstract}
This study was undertaken to examine production performance, pasture and milk intakes and nutrient digestibility in heifers supplemented with different levels of energy in a creep-feeding system on Urochloa decumbens Stapf pastures during the rainy-dry transition season. Fifty-one heifers with predominant Nellore genetic composition (average initial age and weight: 120 days and $133.4 \pm 3.12$ $\mathrm{kg}$ ) and their respective dams were used in an evaluation of production performance, intake, and diet digestibility. Four treatments were evaluated, namely, MM - mineral mixture; T250 - $0.250 \mathrm{~kg}$ of supplement per head per day; T500 - $0.500 \mathrm{~kg}$ of supplement per head per day; and T750 - $0.750 \mathrm{~kg}$ of supplement per head per day, totaling three groups with 13 animals each and one group with 12 animals. All supplements were balanced to provide $100 \mathrm{~g}$ of CP animal $^{-1}$ day $^{-1}$. LIPE $^{\circledR}$ and chromium oxide were used as external markers to estimate fecal excretion and individual DM and supplement intakes, respectively, whereas iNDF was used as an internal marker for pasture DM intake. Production performance did not differ between the supplemented and unsupplemented animals. Total DM intake and pasture DM intake were higher in the group supplemented with concentrate, and the same was observed for the digestibility of DM and NDFap consumed by the animals. The average cow milk yield was $5.33 \mathrm{~kg} /$ day, with average protein and fat contents of $3.51 \%$ and $4.85 \%$, respectively. In conclusion, compared to the use of mineral mixture only, multiple supplementation at different levels containing $100 \mathrm{~g}$ of CP does not significantly improve performance in lactating beef heifers grazing on Urochloa decumbens Stapf and supplemented during the rainy-dry transition season.
\end{abstract}

Key words: Lactating heifers. Urochloa decumbens. Creep-feeding. Energy supplementation.

\section{Resumo}

Objetivou-se avaliar o desempenho produtivo, consumo de pasto e de leite e a digestibilidade dos nutrientes ingeridos por bezerras, suplementadas com diferentes quantidades de energia, em regime de creep-feeding em pastagens de Urochloa decumbens Stapf, durante o período de transição águasseca. Foram utilizadas 51 bezerras com predominância de sangue Nelore e suas respectivas mães, com idades e pesos médios iniciais das bezerras de 120 dias e 133,4 $\pm 3,12 \mathrm{~kg}$, respectivamente, para

\footnotetext{
Prof., Universidade Federal de Goiás, UFG, Goiânia, GO, Brasil. E-mail: victorzootecnista@hotmail.com

Profs., Universidade Federal de Viçosa, UFV, Viçosa, MG, Brasil. E-mail: mpaulino@ufv.br; scvfilho@ufv.br; detmann@ufv.br

Prof., Universidade Federal de Rondônia, UNIR, Presidente Médici, RO, Brasil. E-mail: marlosporto@unir.br

4 Prof., Universidade Estadual do Oeste do Paraná, UNIOESTE, Cascavel, PR, Brasil. E-mail: eritonvalente@yahoo.com.br

5 Discente de Doutorado, UFG, Goiânia, GO, Brasil. E-mail: zoo_belle@hotmail.com

* Author for correspondence
} 
a avaliação do desempenho produtivo, consumo e digestibilidade da dieta. Foram avaliados quatro tratamentos: MM - mistura mineral; T250 - 0,250 kg de suplemento por cabeça por dia; T500 - 0,500 kg de suplemento por cabeça por dia; T750 - $0,750 \mathrm{~kg}$ de suplemento por cabeça por dia; totalizando 3 (três) grupos com 13 (treze) animais cada e um grupo com 12 (doze) animais. Todos os suplementos foram balanceados para fornecerem $100 \mathrm{~g}$ de PB animal ${ }^{-1} \mathrm{dia}^{-1}$. Foram utilizados LIPE $^{\circledR}$ e óxido crômico como indicadores externos para estimativa da excreção fecal e do consumo de MS individual de suplemento, respectivamente e a FDNi como indicador interno para o consumo de MS de pasto. O desempenho dos animais não foi diferente para animais suplementados ou não suplementados. O consumo de MS total e MS de pasto foi maior para os animais suplementados com concentrado, bem como a digestibilidade da MS e da FDNcp ingerida pelos animais. A produção média de leite das vacas foi de 5,33 kg por dia, com média $3,51 \%$ de proteína e $4,85 \%$ de gordura. Com isso, conclui-se que o uso da suplementação múltipla em diferentes níveis, contendo $100 \mathrm{~g}$ de $\mathrm{PB}$, comparado a animais recebendo apenas mistura mineral, não promove melhorias significativas no desempenho de bezerras de corte lactentes sob pastejo em Urochloa decumbens Stapf suplementadas no período de transição águas-seca.

Palavras-chave: Bezerras lactentes. Urochloa decumbens. Creep-feeding. Suplementação energética.

\section{Introduction}

In beef cattle production systems, increased yield and profitability can be achieved through rational use of forage resources and adequate supplementation programs. Optimum pasture utilization should be the primary and invariable goal of farmers, since the forage is the basal nutritional resource to those animals (DETMANN et al., 2014a). However, the decline in nutritional value resulting from the advancing maturation of grasses may lead to protein and energy deficiencies in diets for grazing animals. In general, forages can rarely be considered a balanced diet, as their nutritional concentrations and nutritional attributes do not perfectly match the animal requirements (FIGUEIRAS et al., 2015).

Intense changes take place in the gastrointestinal tract of calves between the third and fifth months of life which ultimately increase their nutrient requirements. Because this phase also coincides with the period of decline in milk production by the cow, the animal is dependent on an adequate external diet (in addition to milk).

The nutritional requirements for weight gain in calves post-weaning cannot be fully met through milk and forage only (MORIEL; ARTHINGTON, 2013). Thus, the use of supplemental feedstuffs during this rearing stage is an intelligent, easily applicable strategy that allows for achieving high gain rates and consequently reducing the production cycle.

Despite the low response to supplementation that is normally attributed to young animals, in a system aiming at efficient production, all stages should be skillfully exploited. Many studies (AGUIAR et al., 2015; MORIEL et al., 2017; NEPOMUCENO et al., 2017) have demonstrated the possibility of improving calf performance via supplementation in a creep-feeding system.

On these bases, the present study proposes to examine production performance, pasture and milk intakes and nutrient digestibility in Nellore or crossbred (predominant Zebu genetic composition) heifers supplemented with different levels of energy in a creep-feeding system on Urochloa decumbens Stapf pastures during the rainy-dry transition season.

\section{Material and Methods}

The experiment was conducted in the Beef Cattle Farming Unit at the Department of Animal Science at the Federal University of Viçosa during the rainy-dry transition season (March to July). The experiment lasted 112 days, which were divided into four 28-day experimental periods.

Fifty-one heifers with predominant Nellore genetic composition and their respective dams were 
used in the study. At the beginning of the experiment, the heifers were 120 days of age, on average, with an average body weight of $133.4 \pm 3.12 \mathrm{~kg}$.

The animals were divided into three groups containing 13 animals each, plus a group with 12 animals. One of the following four treatments was allotted randomly to each group: MM - mineral mixture; T250 - $0.250 \mathrm{~kg}$ of concentrate supplement per head per day; T500 - $0.500 \mathrm{~kg}$ of concentrate supplement per head per day; and T750 - $0.750 \mathrm{~kg}$ of concentrate supplement per head per day. The supplements were formulated to provide, in the total supplied amount, the same amount of CP (Table 1), which was $100 \mathrm{~g}^{\text {anima }}{ }^{-1}$ day $^{-1}$.

Table 1. Centesimal and chemical composition of the supplements and chemical composition of $U$. decumbens.

\begin{tabular}{|c|c|c|c|c|c|}
\hline \multirow{3}{*}{ Ingredient } & \multicolumn{4}{|c|}{ Treatment } & \multirow[b]{2}{*}{ U. decumbens ${ }^{1}$} \\
\hline & MM & $\mathrm{T} 250$ & T500 & $\mathrm{T} 750$ & \\
\hline & \multicolumn{5}{|c|}{ Proportion $(\%)$} \\
\hline \multicolumn{6}{|c|}{ Centesimal composition of the supplements, on an as-is basis ${ }^{2}$} \\
\hline Mineral mixture ${ }^{3}$ & 100.00 & - & - & - & - \\
\hline Urea/AS - 9:1 & - & 1.00 & 0.50 & 0.33 & - \\
\hline Ground corn & - & 17.60 & 71.60 & 89.67 & - \\
\hline Soybean meal & - & 81.40 & 27.90 & 10.00 & - \\
\hline Total & 100.00 & 100.00 & 100.00 & 100.00 & - \\
\hline \multicolumn{6}{|c|}{ Chemical composition of the supplement and of $U$. decumbens, on a dry matter basis } \\
\hline $\mathrm{DM} \%$ & - & 88.94 & 88.54 & 88.41 & $29.86 \pm 1.26$ \\
\hline $\mathrm{OM}^{4}$ & - & 93.69 & 96.88 & 97.95 & $92.45 \pm 0.17$ \\
\hline $\mathrm{CP}^{4}$ & - & 42.54 & 20.17 & 12.64 & $10.26 \pm 0.60$ \\
\hline NDIP $(\% \mathrm{CP})$ & - & 20.53 & 20.81 & 20.90 & $39.37 \pm 0.59$ \\
\hline $\mathrm{EE}^{4}$ & - & 1.86 & 3.45 & 3.99 & $1.53 \pm 0.10$ \\
\hline $\mathrm{NDF}^{4}$ & - & 21.33 & 17.87 & 16.71 & $65.15 \pm 0.43$ \\
\hline NDFap $^{4}$ & - & 12.84 & 13.63 & 13.89 & $59.04 \pm 1.05$ \\
\hline $\mathrm{Ash}^{4}$ & - & 5.19 & 2.56 & 1.67 & $7.55 \pm 0.17$ \\
\hline $\mathrm{NFC}^{4}$ & - & 39.39 & 61.10 & 68.41 & $21.62 \pm .48$ \\
\hline $\mathrm{ADF}^{4}$ & - & 6.95 & 4.75 & 4.01 & $28.07 \pm 1.86$ \\
\hline $\mathrm{iNDF}^{4}$ & - & 1.12 & 1.24 & 1.28 & $18.19 \pm 0.94$ \\
\hline Lignin $^{4}$ & - & 0.07 & 0.18 & 0.22 & $2.89 \pm 0.15$ \\
\hline
\end{tabular}

${ }^{1 /}$ Hand-plucked sample of Urochloa decumbens pasture (grazing simulation). ${ }^{2 /}$ T250 - $250 \mathrm{~g}$ of supplement per head per day; T500 - $500 \mathrm{~g}$ of supplement per head per day; and T750 - $750 \mathrm{~g}$ of supplement per head per day. ${ }^{3 /}$ Centesimal composition: 50.00 dicalcium phosphate; 47.775 sodium chloride; 1.40 zinc sulfate; 0.70 copper sulfate; 0.05 cobalt sulfate; 0.05 potassium iodate, and 0.025 sodium selenite; ${ }^{4 /} \mathrm{DM}$ - dry matter; OM - organic matter; CP - crude protein; NDIP - neutral detergent insoluble protein; EE - ether extract; NDF - neutral detergent fiber; NDFap - ash and protein-free NDF; NFC - non-fibrous carbohydrates; ADF - acid detergent fiber; iNDF - NDF not digested after $240 \mathrm{~h}$ of incubation in the rumen.

Supplements were provided daily, at $10 \mathrm{~h} 00$, in a collective feeder whose dimensions allowed for simultaneous access by the animals. Mineral mixture was supplied ad libitum to all animals. In addition to freely available mineral mixture, the cows received
$100 \mathrm{~g}$ of cornmeal to stimulate their access to the troughs and thus ensure supplement consumption by the heifers. The urea levels in the supplements were established so that all supplemented animals would receive equal daily amounts of this feedstuff. 
The animals were evaluated in an experimental area consisting of four 7.0-ha paddocks uniformly covered with Urochloa decumbens Stapf and equipped with covered drinkers and troughs (separate private troughs for heifers and cows).

All animals were weighed (without previous fasting) at the onset of the experiment and at every 28 days, always in the morning, to reduce possible interferences that might alter intake or compromise performance or data collection.

The animals were rotated across the paddocks fortnightly to eliminate possible differences between them and avoid interference with the results. To monitor animal performance, heifers were weighed and their height was measured and cows were assessed for body condition score (BCS) and weighed at every 28 days.

The change in cow BCS was determined as the difference between initial and final BCS. This variable was assessed using a 9-point scale, as recommended by the NRC (1996). Three duly trained evaluators performed these assessments throughout the experiment.

On the first and last days of each experimental period, forage samples were collected using a $0.25-\mathrm{m}^{2}$ metal square $(50 \times 50 \mathrm{~cm})$, following recommendations of McMeniman (1997). Once collected, each sample was weighed and homogenized and two composite samples were generated out of them: one to evaluate the total dry matter (DM) availability and another to determine the availability of green leaf, dry leaf, green stem, dry stem and total pasture DM. Potentially digestible DM (pdDM) was estimated using the equation described by Paulino et al. (2008).

Samples for the qualitative evaluation of the pasture consumed by the animals were obtained from a manual simulation of the grazing activity, at every 14 days. Along with the samples of concentrate feeds, these were analyzed for the dry matter (DM), organic matter $(\mathrm{OM})$, crude protein $(\mathrm{CP})$, ether extract (EE), ash- and protein-free neutral detergent fiber (NDFap), acid detergent fiber (ADF) and lignin $\left(\mathrm{H}_{2} \mathrm{SO}_{4}, 72 \% \mathrm{p} / \mathrm{p}\right)$ contents, following techniques described by Detmann et al. (2012). Because the supplements contained urea, the non-fibrous carbohydrates (NFC) in them were estimated as recommended by Hall (2000).

Chromium oxide was used for an individual evaluation of intake and digestibility of the ingested diet. LIPE ${ }^{\circledR}$ was used as an external marker to estimate fecal excretion. To estimate the concentrations of LIPE $^{\circledR}$ and chromium oxide on the eighth, ninth and tenth day, feces were collected daily directly from the rectum or immediately after defecation, at $16 \mathrm{~h} 00,12 \mathrm{~h} 00$ and $08 \mathrm{~h} 00$, respectively, aiming to obtain representative fecal samples of each animal during the experimental period.

Individual supplement intake was estimated using chromium oxide as an external marker. This variable was calculated by the following equation: $I S I=F E * M_{F} / M_{S}$, where ISI = individual supplement intake $\left(\mathrm{kg} \mathrm{day}^{-1}\right) ; \mathrm{FE}=$ fecal excretion $\left(\mathrm{kg} \mathrm{day}^{-1}\right) ; \mathrm{M}_{\mathrm{F}}=$ marker concentration in the feces $\left(\mathrm{g} \mathrm{kg}^{-1}\right)$; and $\mathrm{M}_{\mathrm{S}}=$ marker concentration in the supplement $\left(\mathrm{g} \mathrm{kg}^{-1}\right)$.

To quantify milk yield, the cows were separated from their offspring at $18 \mathrm{~h} 00$ on the day before the digestibility trial. The cows were manually milked at $06 \mathrm{~h} 00$ of the next day, totaling $12 \mathrm{~h}$ of production. The obtained value was then multiplied by two to estimate $24-\mathrm{h}$ milk yield. Immediately before milking, the oxytocin hormone was applied to stimulate milk release. Prior to the separation, the heifers were placed in a corral with their dams for 30 min to stimulate them to suckle the residual milk from the udder.

Total voluntary DM intake (DMI) was estimated using indigestible NDF (iNDF) as an internal marker, by the following equation: $D M I\left(\mathrm{~kg} \mathrm{day}^{-1}\right)=$ $\{[(F E \times M C F e)-I M S] / M C F o\}+I S I+M I$, where $\mathrm{FE}=$ fecal excretion $\left(\mathrm{kg} \mathrm{day}{ }^{-1}\right) ; \mathrm{MCFe}=$ marker concentration in the feces $\left(\mathrm{kg} \mathrm{kg}^{-1}\right)$; IMS = intake of internal marker from the supplement $\left(\mathrm{kg} \mathrm{day}^{-1}\right)$, 
$\mathrm{MCFo}=$ marker concentration in the forage $\left(\mathrm{kg} \mathrm{kg}^{-}\right.$ $\left.{ }^{1}\right)$; ISI = individual supplement intake $\left(\mathrm{g} \mathrm{kg}^{-1}\right)$; and $\mathrm{MI}=$ milk dry matter intake $\left(\mathrm{kg} \mathrm{day}^{-1}\right)$.

The iNDF contents in the feces, handplucked pasture samples (grazing simulation) and supplements were obtained after $288 \mathrm{~h}$ of in situ incubation, as suggested by Detmann et al. (2012) da fibra em detergente neutro (FDNi.

The substitution coefficient (SC) of consumed forage for consumed supplement was calculated by the following equation: $S C=(P D M I c-P D M I t) /$ $S D M I$, where PDMIc = average pasture DM intake by the animals in control group; PDMIt = average pasture DM intake by the animals in the treatment in question; and SDMI = average supplement DM intake by the animals in the treatment in question.

On the last day of the digestibility trial, spot urine samples $(10 \mathrm{~mL})$ were collected during spontaneous urination, whereas blood samples were harvested approximately four hours after the supplement was provided. After collection, the urine samples were diluted in $40 \mathrm{~mL}$ of $0.036 \mathrm{~N} \mathrm{H}_{2} \mathrm{SO}_{4}$ and frozen at $-20{ }^{\circ} \mathrm{C}$ for later quantification of the creatinine, urea and purine derivative contents. Blood samples were harvested at the end of the urine collection period in vacuum collection tubes with coagulation accelerator gel. These samples were immediately centrifuged and the serum was frozen at $-20{ }^{\circ} \mathrm{C}$.

Urine samples were analyzed for creatine content by a modified version of Jaffés method and urea and uric acid contents by the enzymaticcolorimetric method. Blood samples were analyzed for urea content by the same method adopted for urine. Commercial kits were used for those analyses.

The daily urinary volume was calculated as the ratio between the daily creatinine excretion (CE), adopting the equation proposed by Chizzotti (2004) as reference, and its concentration in the spot samples. In this way, the daily urinary excretion of nitrogenous compounds was the product between their concentration in the spot samples and the estimated urinary volume.
The allantoin content in urine was measured by the colorimetric method, following Fujihara et al. (1987). Total excretion of purine derivatives was calculated as the sum of the amounts of allantoin and uric acid excreted in urine, and expressed as mmol day-1.

Absorbed purines (X, mmol day-1) were determined from the excretion of purine derivatives, by the following equation: $Y=(X-0.385 B W 0.75)$ $/ 0.85$, where 0.85 is the recovery of absorbed purines as purine derivatives and $0.385 \mathrm{BW} 0.75$ is the endogenous contribution to purine excretion (VERBIC et al., 1990)

The ruminal synthesis of nitrogenous compounds (Y, g micN day-1) was calculated as a function of absorbed purines (X, mmol day-1), using the equation described by Chen and Gomes (1992), except for the purine $\mathrm{N}$ :total bacterial $\mathrm{N}$ ratio of 0.134, following Valadares et al. (1999)formulated from alfalfa silage plus a concentrate mix based on ground high moisture ear corn, contained (dry matter basis.

Statistical analyses for animal performance data were carried out considering a completely randomized experimental design. The observed means were compared by decomposing the sum of squares of treatments into orthogonal contrasts relative to the comparison between supplementation and non-supplementation and to the linear and quadratic effects as a function of the amount of supplement, with subsequent regression-equation fittings. The statistical procedures were performed using SAS computer software, adopting 0.10 as the critical level of type-I error probability.

\section{Results and Discussion}

Supplementation treatments T250, T500 and T750 contained 42.54, 20.17 and $12.64 \% \mathrm{CP}$ (Table 1) and provided 106.34, 100.85 and 94.82 g CP animal ${ }^{-1}$ day $^{-1}$, respectively, in their supplied amounts. 
Despite the low leaf:stem ratio (30:70) observed in the pasture (Figure 1), the hand-plucked sample (grazing simulation representing the forage selected by the heifers) exhibited elevated nutrient concentrations, especially $\mathrm{CP}$, demonstrating the high selectivity of young calves when grazing.
To ensure that the sample representing the forage harvested by the heifers was reliable, the animals were closely monitored in all experimental period for some time prior to the start of collection and throughout it. The hand-plucked forage had an average CP content of $10.26 \%$ (Table 1).

Figure 1. Availability of potentially digestible dry matter (pdDM), green leaf, dry leaf, green stem, dry stem and total $\mathrm{DM}$ of forage (sum of the last four items) in the months of the experimental period and average of the entire period in tons of DM per hectare.

\section{Disponibility of Forage}

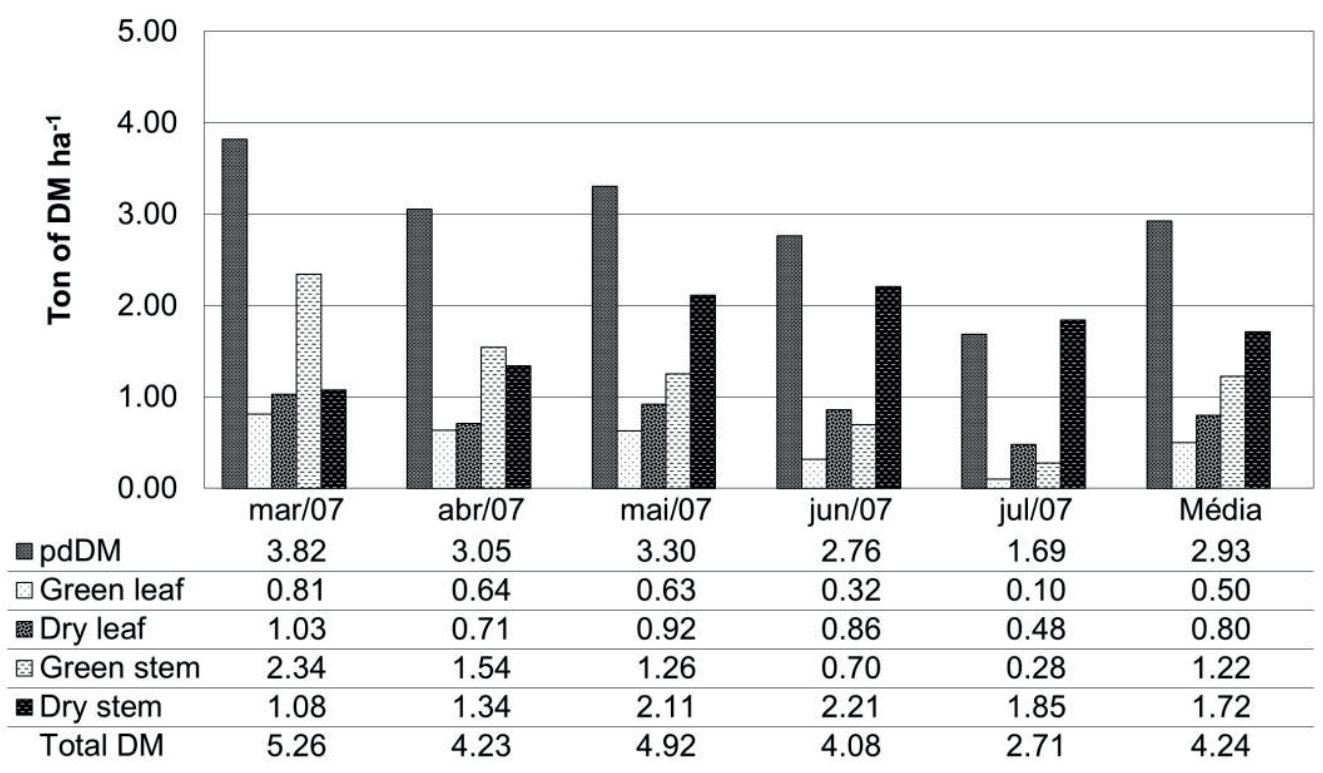

Detmann et al. (2014b) reported that CP values near $10 \%$ in the diet ensure the availability of nitrogenous compounds to microorganisms for the synthesis of the enzymatic systems responsible for the degradation of fibrous carbohydrates from the forage. However, the advanced age of the animals used in the above-mentioned studies compared to those used in the current experiment is a factor to be taken into account, since young animals do not have the same ruminal-environment conditions as adult animals. Thus, higher protein levels in the supplements might result in better performance for the supplemented animals, considering that their protein requirements are higher because they were still in the growth phase.
Accumulated precipitation and mean temperatures during the months of March, April, May and June were $32.4 \mathrm{~mm}$ and $22.3^{\circ} \mathrm{C} ; 43.3 \mathrm{~mm}$ and $21.2{ }^{\circ} \mathrm{C}$; $14.7 \mathrm{~mm}$ and $17.5^{\circ} \mathrm{C}$; and $2.2 \mathrm{~mm}$ and $16.2{ }^{\circ} \mathrm{C}$, respectively. The average availability of potentially digestible forage throughout the experiment in the paddocks was $2,925 \mathrm{~kg} \mathrm{DM} \mathrm{ha}{ }^{-1}$ (Figure 1), thus representing $4.8 \%$ of body weight of herbage allowance to the animals. This value is in agreement with the standards suggested by Paulino et al. (2008) for animal production per area and pasture utilization efficiency. Approximately 40\% of the pasture DM was represented by green and dry stem, which are slowly and poorly digestible components. This fact was proved in this study, 
where the digestibility of the DM consumed by the animals supplemented with mineral mixture only (besides milk) was 5.7\% lower $(\mathrm{P}>0.05)$ than that in the animals which received multiple supplements (61.5\% vs. 65.0\%) (Table 2). A 68.2\% decrease was observed in leaf availability, with green leaf decreasing by $87.4 \%$ from the first to the last experimental period. Meanwhile, total DM availability dropped by $51.4 \%$, demonstrating that the animals select their feed on the pasture and that the composite sample of all available DM is not representative to qualitatively evaluate the material ingested by the animals. Therefore, a manual simulation of the grazing activity is required.

Table 2. Mean intake values of total DM (TDM), pasture DM (PDM), milk, organic matter (OM), CP, EE, NDFap, NFC and TDN; substitution coefficient (SC); DM digestibility (DMD); NDFap digestibility (NDFapD); coefficients of variation; and descriptive probability levels for type-I error of the studied contrasts.

\begin{tabular}{|c|c|c|c|c|c|c|c|c|}
\hline \multirow{2}{*}{ Intake } & \multicolumn{4}{|c|}{ Treatment } & \multirow{2}{*}{$\begin{array}{l}\text { CV } \\
(\%)\end{array}$} & \multicolumn{3}{|c|}{ Contrast $^{1}$} \\
\hline & $\mathrm{MM}$ & $\mathrm{T} 250$ & T500 & $\mathrm{T} 750$ & & CONT & $\mathrm{L}$ & $\mathrm{Q}$ \\
\hline $\mathrm{TDM}^{2}$ & 3.112 & 3.810 & 3.651 & 3.739 & 16.7 & 0.0023 & 0.7634 & 0.5567 \\
\hline TDM $(\% \mathrm{BW})$ & 1.91 & 2.33 & 2.02 & 2.24 & 22.4 & 0.0725 & 0.6498 & 0.1207 \\
\hline $\mathrm{PDM}^{2,5}$ & 2.274 & 2.878 & 2.538 & 2.279 & 18.1 & 0.0498 & 0.0014 & 0.7958 \\
\hline $\operatorname{PDM}(\% \mathrm{BW})^{6}$ & 1.40 & 1.76 & 1.41 & 1.37 & 25.5 & 0.3599 & 0.0113 & 0.2385 \\
\hline Milk $^{3}$ & 5.94 & 5.25 & 4.93 & 5.19 & 29.5 & 0.2444 & 0.9422 & 0.6884 \\
\hline $\mathrm{OM}^{2}$ & 2.923 & 3.564 & 3.431 & 3.538 & 16.8 & 0.0022 & 0.9080 & 0.5447 \\
\hline $\mathrm{CP}^{2}$ & 0.436 & 0.566 & 0.512 & 0.522 & 16.0 & 0.0005 & 0.1745 & 0.2607 \\
\hline $\mathrm{EE}^{2,7}$ & 0.329 & 0.275 & 0.280 & 0.347 & 4.8 & $<0.0001$ & $<0.0001$ & $<0.0001$ \\
\hline $\mathrm{NDFap}^{2,8}$ & 1.343 & 1.728 & 1.559 & 1.438 & 18.3 & 0.0121 & 0.0104 & 0.8018 \\
\hline $\mathrm{NFC}^{2,9}$ & 0.816 & 0.999 & 1.083 & 1.236 & 23.8 & 0.0006 & 0.0178 & 0.6971 \\
\hline $\mathrm{TDN}^{2}$ & 2.224 & 2.742 & 2.591 & 2.788 & 20.6 & 0.0071 & 0.8288 & 0.3536 \\
\hline $\mathrm{SC}$ & - & -2.72 & -0.60 & -0.01 & - & - & - & - \\
\hline $\mathrm{DMD}^{4}$ & 61.5 & 65.6 & 63.9 & 65.5 & 7.4 & 0.0254 & 0.9686 & 0.3176 \\
\hline $\mathrm{NDFapD}^{4,10}$ & 53.6 & 60.5 & 57.2 & 54.4 & 10.5 & 0.0533 & 0.0108 & 0.9125 \\
\hline
\end{tabular}

${ }^{1 /}$ Descriptive probability levels for type-I error for the contrast. CONT, control vs. supplemented treatments; L - linear and Q quadratic. ${ }^{2 /}$ Intake in kg per animal per day. ${ }^{3 /}$ Milk intake in $\mathrm{kg}$ of dry matter per animal per day. ${ }^{4 /}$ Digestibility in $\% .{ }^{5 /} \hat{\mathrm{Y}}=3.164$ $-0.2995 \mathrm{X}\left(\mathrm{r}^{2}=0.9939\right) .{ }^{6 /} \hat{\mathrm{Y}}=1.9033-0.195 \mathrm{X}\left(\mathrm{r}^{2}=0.8260\right) .{ }^{7 /} \hat{\mathrm{Y}}=0.332-0.088 \mathrm{X}+0.031 \mathrm{X}^{2}\left(\mathrm{r}^{2}=1.0000\right) .{ }^{8 /} \hat{\mathrm{Y}}=1.865-0.145 \mathrm{X}$ $\left(r^{2}=0.9910\right) .{ }^{9 /} \hat{Y}=0.869+0.1185 X\left(r^{2}=0.9725\right) .{ }^{10 /} \hat{Y}=63.467-3.05 X\left(r^{2}=0.9978\right)$.

Milk intake was not affected by the treatments ( $\mathrm{P}>0.10$ ), averaging $5.33 \mathrm{~kg} \mathrm{day}^{-1}$ (Table 2). The milk contained approximately $3.51 \%$ protein, $4.85 \%$ fat and $13.85 \%$ total solids.

Several factors associated with the physical structure of the pasture, animal behavior and mainly the nutritional composition of the forage influence total DM intake. In tropical conditions, where the animal diet is high in fiber, feed intake always depends on the degradation of the previously ingested material and also on the output of the undigested material, since the physical fill of the gastrointestinal tract limits the entry of new feed. Thus, coupled with the lower digestibility of DM $(\mathrm{P}<0.01)$, the total DM intake of the animals from control group was approximately 20.0\% lower $(\mathrm{P}<0.10)$ than that shown by the supplemented animals (Table 2).

The highest NFC intake (Table 2) was found in the supplemented heifers $(\mathrm{P}<0.01)$ as well as at 
the highest supplementation level $(\mathrm{P}<0.05)$. The NFC concentration in the supplement rose from $39.39 \%$ to $68.41 \%$ from the lowest to the highest supplementation level (Table 2). Thus, as the diet supplementation level was elevated (the energy level, basically), the NDFap digestibility among the supplemented animals decreased $(\mathrm{P}<0.05)$, consequently reducing pasture DM intake $(\mathrm{P}<0.01)$. A high concentration of NFC in the diet prompts greater growth of non-fibrolytic over fibrolytic microorganisms (the "carbohydrate effect"). This fact was aggravated by the decreasing protein content in the supplements as the supplementation level was raised, considering that these microorganisms compete for the nitrogen present in the rumen. As NFC increases, the rumen $\mathrm{pH}$ decreased. Sari et al. (2015) reported a result similar to that found in the present study, with decreased NDF digestibility when the rumen $\mathrm{pH}$ value was low.

Although the change in cow BCS (Table 3) was not influenced by the treatments $(\mathrm{P}>0.10)$, the dams of the supplemented heifers lost less weight $(\mathrm{P}<0.05)$ throughout the experiment than those which raised non-supplemented heifers ( $2.35 \mathrm{vs} .17 .54 \mathrm{~kg}$ ). This fact may be associated with the greater dependence of a calf on its dam. Heifer supplementation did not influence the final BCS of their dams.

Table 3. Mean values for initial body weight (IBW), final body weight (FBW), total body weight gain (TWG), average daily gain (ADG), gain in body height (GBH), gain in body length (GBL), change in cow body weight (CCBW), change in cow body condition score (CCBCS) and final cow BCS (FCBCS); coefficients of variation (CV) and descriptive probability levels for type-I error of the studied contrasts.

\begin{tabular}{|c|c|c|c|c|c|c|c|c|}
\hline & \multicolumn{4}{|c|}{ Treatment } & \multirow{2}{*}{ CV (\%) } & \multicolumn{3}{|c|}{ Contrast $^{1}$} \\
\hline & MM & $\mathrm{T} 250$ & $\mathrm{~T} 500$ & $\mathrm{~T} 750$ & & CONT & $\mathrm{L}$ & Q \\
\hline $\mathrm{IBW}^{2}$ & 134.1 & 130.2 & 139.1 & 130.7 & - & - & - & - \\
\hline $\mathrm{FBW}^{2}$ & 194.1 & 186.1 & 206.5 & 198.3 & 13.2 & 0.7293 & 0.2325 & 0.1185 \\
\hline $\mathrm{TWG}^{2,4}$ & 60.0 & 55.9 & 67.4 & 67.6 & 19.9 & 0.3662 & 0.0207 & 0.2002 \\
\hline $\mathrm{ADG}^{2,5}$ & 0.536 & 0.499 & 0.602 & 0.604 & 19.9 & 0.3664 & 0.0208 & 0.1998 \\
\hline $\mathrm{GBH}^{3,6}$ & 10.3 & 9.2 & 9.9 & 11.3 & 30.0 & 0.8745 & 0.0896 & 0.7424 \\
\hline $\mathrm{GBL}^{3,7}$ & 15.7 & 12.7 & 14.3 & 16.6 & 38.8 & 0.8745 & 0.0892 & 0.8741 \\
\hline $\mathrm{CCBW}^{2}$ & -17.5 & -4.2 & 1.4 & -4.2 & -350.4 & 0.0373 & 0.9999 & 0.4668 \\
\hline CCBCS & -0.2 & -0.3 & -0.3 & 0.0 & -224.8 & 0.9401 & 0.1014 & 0.4722 \\
\hline FCBCC & 3.8 & 3.8 & 3.9 & 3.9 & 16.1 & 0.5985 & 0.5639 & 0.6299 \\
\hline
\end{tabular}

${ }^{1 /}$ Descriptive probability levels for type-I error for the contrast. CONT, control vs. supplemented treatments; L - linear and Q quadratic. ${ }^{2 /}$ values in kg. ${ }^{3 /}$ values in $\mathrm{cm} .{ }^{4 /} \hat{\mathrm{Y}}=51.933+5.85 \mathrm{X}\left(\mathrm{r}^{2}=0.7628\right) .{ }^{5 /} \hat{\mathrm{Y}}=0.4633+0.0525 \mathrm{X}\left(\mathrm{r}^{2}=0.7643\right) .{ }^{6 / \hat{\mathrm{Y}}}=8.0333+$ $1.05 \mathrm{X}\left(\mathrm{r}^{2}=0.9643\right) .{ }^{7 /} \hat{\mathrm{Y}}=10.633+1.95 \mathrm{X}\left(\mathrm{r}^{2}=0.9894\right)$.

Despite the low quality of available forage ( $60 \%$ of $\mathrm{DM})$, the high selectivity commonly observed in the studied animal category (young calves) resulted in consumption of high-quality forage. As a consequence, animal performance was not limited, since no difference was found in total weight gain (TWG), average daily gain (ADG), or final body weight between the supplemented or unsupplemented animals $(\mathrm{P}>0.10)$ (Table 3$)$. One of the factors that might have contributed to this result is the low amount of protein $\left(100 \mathrm{~g}\right.$ of $\mathrm{CP}$ animal ${ }^{-1}$ day $^{-1}$ ) offered through the supplements, since that the requirements of those animals, considering a weight gain of $600 \mathrm{~g} \mathrm{day}^{-1}$, is around $650 \mathrm{~g}$ of $\mathrm{CP}_{\text {day }}{ }^{-}$ 1 , according to the NRC (2001). The offered dose may be considered insufficient to provide adequate utilization of the energy from the supplements and the pasture. Among the supplemented animals, 
a positive linear effect of supplementation was observed on TWG, ADG and growth in height and length. In spite of the linear effect for ADG, the observed value at the highest supplementation level was very close to that obtained at the previous level, indicating a reduction in the efficiency of use of the energy present in the supplement. The low genetic quality of the evaluated animals might have also contributed to this lack of response to supplementation.

The treatments did not influence daily microbial production $(\mathrm{P}>0.10)$, which supports the hypothesis that the protein dose offered in the supplements was not sufficient to improve microbial growth (Table 4).
The lower urea $\mathrm{N}$ value found in the blood serum (Table 4) of the animals receiving higher supplementation levels $(\mathrm{P}<0.01)$ underpins the theory that animals receiving high levels of NFC have higher protein requirements, given the high competitiveness for this nutrient in the rumen environment. This fact is confirmed by the greater efficiency using the ingested nitrogen as suggested by the lower urine urea nitrogen content $(\mathrm{P}<0.05)$ (lower losses). These results are in line with those published by Al-Marashdeh et al. (2016), who found a lower urinary nitrogen excretion in animals supplemented with carbohydrates from low-protein diets.

Table 4. Means, coefficients of variation (CV) and descriptive probability levels of microbial nitrogen compound production (micN, g/day), serum urea nitrogen ( $\mathrm{SUN}, \mathrm{mg} / \mathrm{dL}$ ), urine urea nitrogen (UUN, g/day), microbial efficiency in $\mathrm{g}$ of micCP/kg of TDN consumed (MEf) and microbial efficiency in micN/total N intake (micN/Nint, \%).

\begin{tabular}{|c|c|c|c|c|c|c|c|c|}
\hline & \multicolumn{4}{|c|}{ Treatment } & \multirow{2}{*}{$\mathrm{CV}(\%)$} & \multicolumn{3}{|c|}{ Contrast $^{1}$} \\
\hline & MM & $\mathrm{T} 250$ & T500 & $\mathrm{T} 750$ & & CONT & $\mathrm{L}$ & Q \\
\hline micN & 31.14 & 30.46 & 29.72 & 31.96 & 29.6 & 0.8866 & 0.6772 & 0.6425 \\
\hline $\mathrm{SUN}^{2}$ & 17.47 & 17.62 & 10.91 & 11.75 & 37.5 & 0.0253 & 0.0085 & 0.0526 \\
\hline $\mathrm{UUN}^{3}$ & 17.45 & 27.00 & 24.11 & 20.76 & 32.2 & 0.0070 & 0.0313 & 0.9267 \\
\hline \multicolumn{9}{|c|}{ Microbial efficiency } \\
\hline MEf & 88.37 & 72.90 & 74.54 & 74.88 & 36.2 & 0.1209 & 0.8584 & 0.9469 \\
\hline $\mathrm{micN} / \mathrm{Nint}$ & 44.91 & 34.23 & 37.36 & 38.92 & 32.4 & 0.0516 & 0.3465 & 0.8596 \\
\hline
\end{tabular}

${ }^{1 /}$ Descriptive probability levels for type-I error for the contrast. CONT, control vs. supplemented treatments; L - linear and Q quadratic. ${ }^{2 /} \hat{\mathrm{Y}}=31.88-18.035 \mathrm{X}+3.775 \mathrm{X}^{2}\left(\mathrm{r}^{2}=1.0000\right) .{ }^{3 /} \hat{\mathrm{Y}}=30.197-3.12 \mathrm{X}\left(\mathrm{r}^{2}=0.9982\right)$.

\section{Conclusions}

Compared to the use of mineral mixture alone, multiple supplementation at different levels containing $100 \mathrm{~g}$ of $\mathrm{CP}$ does not significantly improve performance in lactating beef heifers grazing on Urochloa decumbens Stapf pastures and supplemented in a creep-feeding system during the rainy-dry transition season. A maximum difference of $12.7 \%$ is observed between the means of supplemented and unsupplemented animals. Among supplemented animals, higher supplementation levels lead to better performance.

\section{References}

AGUIAR, A. D.; VENDRAMINI, J. M. B.; ARTHINGTON, J. D.; SOLLENBERGER, L. E.; CAPUTTI, G.; SANCHEZ, J. M. D.; CUNHA, O. F. R.; SILVA, W. L. da. Limited creep-feeding supplementation effects on performance of beef cows and calves grazing limpograss pastures. Livestock Science, Almsford, v. 180, p. 129-133, 2015. DOI: 10.1016/j.livsci.2015.08.008

AL-MARASHDEH, O.; GREGORINI, P.; EDWARDS, G. R. Effect of time of maize silage supplementation on herbage intake, milk production, and nitrogen excretion of grazing dairy cows. Journal of Dairy Science, Champaign, v. 99, n. 9, p. 7123-7132, 2016. DOI: $10.3168 /$ jds. $2015-10681$ 
CHEN, X. B.; GOMES, M. J. Estimation of microbial protein supply to sheep and cattle based on urinary excretion of purine derivatives: an overview of the technical details. Occasional publication of the International Feed Resources Unit. Aberdeen: Rowett Research Institute, 1992. 22 p.

CHIZZOTTI, M.L. Avaliação da casca de algodão para novilhos de origem leiteira e determinação da excreção de creatinina e produção de proteína microbiana em novilhas e vacas leiteiras. 2004. Dissertação (Mestrado em Zootecnia) - Universidade Federal de Viçosa, Viçosa, MG, 2004.

DETMANN, E.; SOUZA, M. A.; VALADARES FILHO, S. C.; QUEIROZ, A. C.; BERCHIELLI, T. T.; SALIBA, E. O. S.; AZEVEDO, J. A. G. (Ed.). Métodos para análise de alimentos-Instituto Nacional de Ciência e Tecnologia em Ciência Animal. Visconde do Rio Branco, MG: Suprema, 2012. 214 p.

DETMANN, E.; VALADARES FILHO, S. C.; PAULINO, M. F.; HUHTANEN, P. Nutritional aspects applied to grazing cattle in tropics: a review based on Brazilian results. Semina: Ciências Agrárias, Londrina, v. 35, n. 4, p. 2829-2854, 2014a. DOI: 10.5433/1679-0359.2014v35n4Suplp2829

DETMANN, E.; VALENTE, É. E. L.; BATISTA, E. D.; HUHTANEN, P. An evaluation of the performance and efficiency of nitrogen utilization in cattle fed tropical grass pastures with supplementation. Livestock Science, Almsford, v. 162, n. 1, p. 141-153, 2014b. DOI: 10.1016/j. livsci.2014.01.029

FIGUEIRAS, J. F.; DETMANN, E.; VALADARES FILHO, S. C.; PAULINO, M. F.; BATISTA, E. D.; RUFINO, L. M. A.; VALENTE, T. N. P.; REIS, W. L. S.; FRANCO, M. O. Desempenho nutricional de bovinos em pastejo durante o período de transição seca águas recebendo suplementação proteica. Archivos de Zootecnia, Córdoba, v. 64, n. 247, p. 269-276, 2015. DOI: 10.21071/az.v64i247.401

FUJIHARA, T.; ORSKOV, E. R.; REEDS, P. J.; KYLE, D. J. The effect of protein infusion on urinary excretion of purine derivatives in ruminants nourished by intragastric nutrition. Journal of Agricultural Science, Cambridge, v. 109 , n. 1, p. 7-12, 1987. DOI: $10.1017 /$ S0021859600080916

HALL, M. B. Calculation of non-structural carbohydrate content of feeds that contain non-protein nitrogen. Gainesville: University of Florida, 2000. 76 p. (Bulletin, 339).

MCMENIMAN, N. P. Methods of estimating intake of grazing animals. In: SIMPÓSIO SOBRE TÓPICOS ESPECIAIS EM ZOOTECNIA; REUNIÃO ANUAL
DA SOCIEDADE BRASILEIRA DE ZOOTECNIA, 34., Juiz de Fora. Anais... Juiz de Fora: Sociedade Brasileira de Zootecnia, 1997. p. 131-168.

MORIEL, P.; ARTHINGTON, J. D. Effects of molassesbased creep-feeding supplementation on growth performance of pre- and post-weaned beef calves. Livestock Science, Almsford, v. 151, n. 2-3, p. 171-178, 2013. DOI: $10.1016 /$ j.livsci.2012.11.008

MORIEL, P.; VENDRAMINI, J. M. B.; ARTHINGTON, J. D.; AGUIAR, A. D.; CAPUTTI, G. Effects of crude protein level and degradability of limited creep-feeding supplements on performance of beef cow-calf pairs grazing limpograss pastures. Livestock Science, Almsford, v. 200 , p. $1-5$, 2017. DOI: 10.1016/j.livsci.2017.03.020

NATIONAL RESEARCH COUNCIL - NRC. Nutrient requirements of beef cattle. 6th ed. Washington: National Academy Press, 1996. 242 p.

NATIONAL RESEARCH COUNCIL - NRC. Nutrient Requirements of dairy cattle. 7th ed. Washington: National Academy Press, 2001. 381 p.

NEPOMUCENO, D. D.; PIRES, A. V.; FERRAZ, M. V. C.; BIEHL, M. V.; GONÇALVES, J. R. S.; MOREIRA, E. M.; DAY, M. L. Effect of pre-partum dam supplementation, creep-feeding and post-weaning feedlot on age at puberty in Nellore heifers. Livestock Science, Almsford, v. 195, p. 58-62, 2017. DOI: 10.1016/j. livsci.2016.11.008

PAULINO, M. F.; DETMANN, E.; VALADARES FILHO, S. C. Bovinocultura funcional nos trópicos. In: SIMPÓSIO DE PRODUÇÃO DE GADO DE CORTE, 2., 2008, Viçosa, MG. Anais... Viçosa: SIMCORTE, 2008. p. 275-309.

SARI, M.; FERRET, A.; CALSAMIGLIA, S. Effect of $\mathrm{pH}$ on in vitro microbial fermentation and nutrient flow in diets containing barley straw or non-forage fiber sources. Animal Feed Science and Technology, Amsterdam, v. 200, n. 1, p. 17-24, 2015. DOI: 10.1016/j. anifeedsci.2014.11.011

VALADARES, R. F. D.; BRODERICK, G. A.; VALADARES FILHO, S. C.; CLAYTON, M. K. Effect of replacing alfalfa silage with high moisture corn on ruminal protein synthesis estimated from excretion of total purine derivatives. Journal of Dairy Science, Champaign, v. 82 , n. 12 , p. $2686-2696,1999$. DOI: $10.3168 /$ jds.S0022-0302(99)75525-6

VERBIC, J.; CHEN, X. B.; MACLEOD, N. A.; ORSKOV, E. R. Excretion of purine derivatives by ruminants: effect of microbial nucleic acid infusion on purine derivative excretion by steers. Journal of Agricultural Science, Cambridge, v. 114, n. 3, p. 243-248, 1990. DOI: $10.1017 /$ S0021859600072610 